\title{
De la oscuridad al jardín en unas memorias alucinadas: La oscuridad es otro sol, de Olga Orozco ${ }^{1}$
}

\author{
INMACULADA LERGO MARTÍN
}

Academia Peruana de la Lengua

Resumen: La oscuridad es otro sol (1967) es el primero de los dos libros en prosa publicados por la poeta argentina Olga Orozco (Toay, 1920-Buenos Aires, 1999), una de las voces fundamentales de la poesía en español del siglo XX. Es un conjunto unitario de relatos de gran valor literario, que además nos proporciona las claves interpretativas de su poética. Con base autobiográfica, a través de la mirada mágica e incontaminada de la niña Lía -alter ego de la autora-, y desdibujando los contornos con la Olga adulta que escribe, Orozco narra los hechos que conformaron su infancia, en un entorno onírico, feérico y mágico de tonos surrealistas. Con todos los recuerdos y recursos a su alcance, incluidos aquellos inaprensibles que debe forzar a través de lo extrasensorial, la autora intenta violentar y trascender el tiempo, el espacio y el yo materiales y limitados para acceder al conocimiento y unidad con la esencia divina perdidas tras el nacimiento.

Palabras clave: Olga Orozco, poesía argentina, La oscuridad es otro sol, surrealismo. 


\section{From Darkness to a Garden in Hallucinated Memories. La oscuridad es otro sol, by Olga Orozco}

Abstract: La oscuridad es otro sol (1967) is the first of the two books of prose published by the Argentine poet Olga Orozco (Toay, 1920-Buenos Aires, 1999), one of the essential voices in Spanish-language poetry of the twentieth century. The book is a unified set of stories of great literary value that also offers us the interpretive keys to Orozco's poetics. Starting with Orozco's autobiography, the stories are recounted through the magical and uncontaminated gaze of the little girl Lía, the author's alter ego, blurring the circumstances of the writing by the adult Orozco. The author narrates the facts of her childhood in an oneiric, magical, and fairy tale-like setting with surrealist overtones. With all the memories and resources at her disposal, including the ineffable ones that require recourse to extrasensory perception, the author tries to ravage and transcend time, space, and the self in their material, limited forms in order to reach knowledge and unity with the divine essence that are lost after birth.

Key words: Olga Orozco, Argentine poetry, La oscuridad es otro sol, surrealism.

I n 1967 la editorial Losada publicó La oscuridad es otro sol, primer libro en prosa de Olga Orozco, que salía tras los poemarios Desde lejos (1946), Las muertes (1951) y Los juegos peligrosos (1962); veintiocho años después, en la recta final de su trayectoria literaria y vital, y tras haber editado seis poemarios más -Museo salvaje (1974), Cantos a Berenice (1977), Mutaciones de la realidad (1979), La noche a la deriva (1983), En el revés del cielo (1987) y Con esta boca, en este mundo (1994), da a la imprenta un segundo volumen de cuentos, También la luz es un abismo (1995), último libro que publica en vida. Póstumamente, Ana Becciú sacó sus Últimos poemas (2009), con el material que se encontraba en unas carpetas ordenadas y dejadas por Orozco sobre su escritorio antes de ir al hospital -para una intervención quirúrgica- del que ya no volvió. 
La consideración -repetida en demasiadas ocasiones- de que en su prosa, especialmente en La oscuridad es otro sol, se pueden encontrar las claves de la poesía de la autora y, por lo tanto, resulta muy útil para desentrañar su poesía -lo cual es sin duda cierto-, ha propiciado quizás una menor atención desde otros acercamientos. Es necesario pues comenzar afirmando que el valor de la prosa de Orozco es, per se, de igual valía que su poesía, independientemente de que en una lectura total de su obra sus cuentos resulten reveladores de su universo poético. Sí lo son y en gran medida, tanto para su obra poética como para la de prosa, las múltiples entrevistas que concedió, cuya lectura es ineludible ${ }^{2}$. Quizá también esta descompensación respecto a su obra en prosa se haya visto mediatizada, como apuntaba María Elena Legaz, por el hecho de que La oscuridad es otro sol se publicó en pleno auge de la narrativa hispanoamericana, el llamado «boom», el mismo año «del deslumbramiento provocado por Cien años de soledad» de Gabriel García Márquez (1993: 376). Pero dejemos a un lado estas consideraciones ajenas al acto creador y adentrémonos en lo posible, aunque muy brevemente, en el intrincado bosque de La oscuridad es otro sol, para poder compartir con la protagonista -y en paralelo con la autora- esa enmarañada y espinosa oscuridad alumbrada de vez en cuando por destellos a modo de relámpagos que, entre el follaje y el misterio, van permitiendo vislumbrar el camino hacia ese jardín cuya existencia y luz se perciben siempre al fondo.

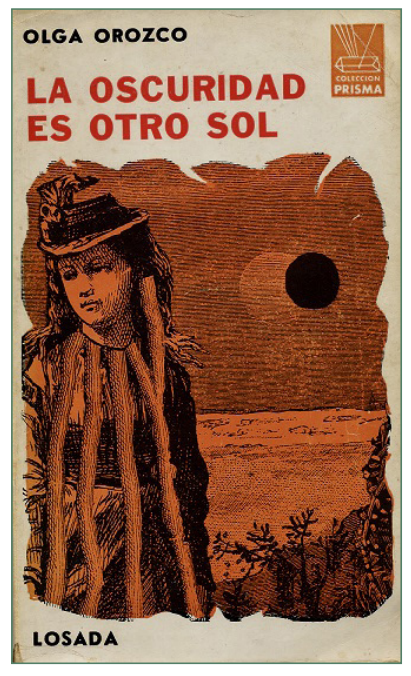

La oscuridad es otro sol es un conjunto de quince relatos en los que la niña Lía -alter ego de Orozcorefiere los hechos, los lugares y las personas que conformaron su mundo de infancia. Se ofrecen en diferentes cuentos independientes, pero que constituyen una unidad y continuidad en que se desdibujan por momentos los contornos entre la Olga niña protagonista y la adulta que escribe, para ser una sola, en un entorno onírico, mágico y surrealista que tiene mucho que ver también con el psicoanálisis. Esta técnica de indagación de la mente atrajo la atención de Orozco, e incluso se sometió a él durante un tiempo. Su práctica fue introducida en Argentina en esos años por Enrique Pichón Rivière y Arminda Aberasturi, a quienes Olga conoció. Cuenta Olga Orozco en una entrevista con Gloria Alcorta, que su 
psicólogo la hacía escribir unas horas dos o tres veces por semana y que ella «anotaba recuerdos, sueños, lo que fuere, y empezaron a salir muchas cosas antiguas». Cuando el doctor le dio el alta, le entregó todo ese material diciéndole que ahí tenía un libro: «Y así empezó a surgir La oscuridad es otro sol, que continué en También la luz es un abismo» (Requeni, 1997: 131-132). El libro es además y juntamente «el abordaje narrativo de lo planteado poéticamente [...] en Los juegos peligrosos», por lo que es enriquecedora una lectura que los relacione a ambos. La propia Orozco confirma que decidió volver a la prosa porque necesitaba ordenar el trayecto recorrido hasta ese momento (Legaz, 1993: 376). Por eso sabemos que el personaje principal y voz narrativa, Lía, es ella misma, que los escenarios corresponden a los de su infancia en la Pampa, que los hechos son recreados por la memoria de vivencias personales y que los demás personajes son también todas las personas que la rodearon en esa época ${ }^{3}$. Con estos elementos, y con «las constantes del asombro, el miedo y las variantes lúdicas que emergen de su fantasía interior», Orozco da paso a los grandes temas de su poética (Ruano, 2000: XI). Es esencial en este caso tener en cuenta que la memoria aquí no es rememoración, sino más bien, como la define Zabaljáuregui, «un gran malström, una corriente vertiginosa y fundante» (1998: 14), que nos ofrece esplendidas imágenes oníricas dentro de lo mejor de la literatura surrealista del momento. Pese a que -nos advierte Manuel Ruano- su «experiencia surreal es más intuitiva que metodológica» y a que, dentro de esta tendencia, Orozco «no es ortodoxa en los lineamientos respecto a la escritura automática» ni a otros «automatismos psíquicos tan en boga de los experimentos surreales» (2000: XXVIII), hay elementos comunes, que la propia autora reconoce en -entre otros- «la creencia en una realidad sin límites, más allá de toda apariencia y toda superficie y la avidez de captar esa realidad por entero en todos sus planos» (cit. en Ruano, 2000: XXVIII). Es por eso que los collages surrealistas que su amigo el poeta Enrique Molina le cedió para acompañar al texto y para la cubierta fueron el complemento perfecto a la primera edición, y un empobrecimiento el que no aparezcan en ediciones posteriores.

3 Es muy esclarecedora en este sentido la lectura hecha por Jorgelina Loubet en presencia de Olga -y de Hugo Mujica y Gabriela Rebok-, para conmemorar los veinte años de su publicación. Loubet, así como sus acompañantes, por su íntima amistad con la autora, conoció muy de cerca las circunstancias personales que rodearon su gestación y escritura (Loubet, 2010). 

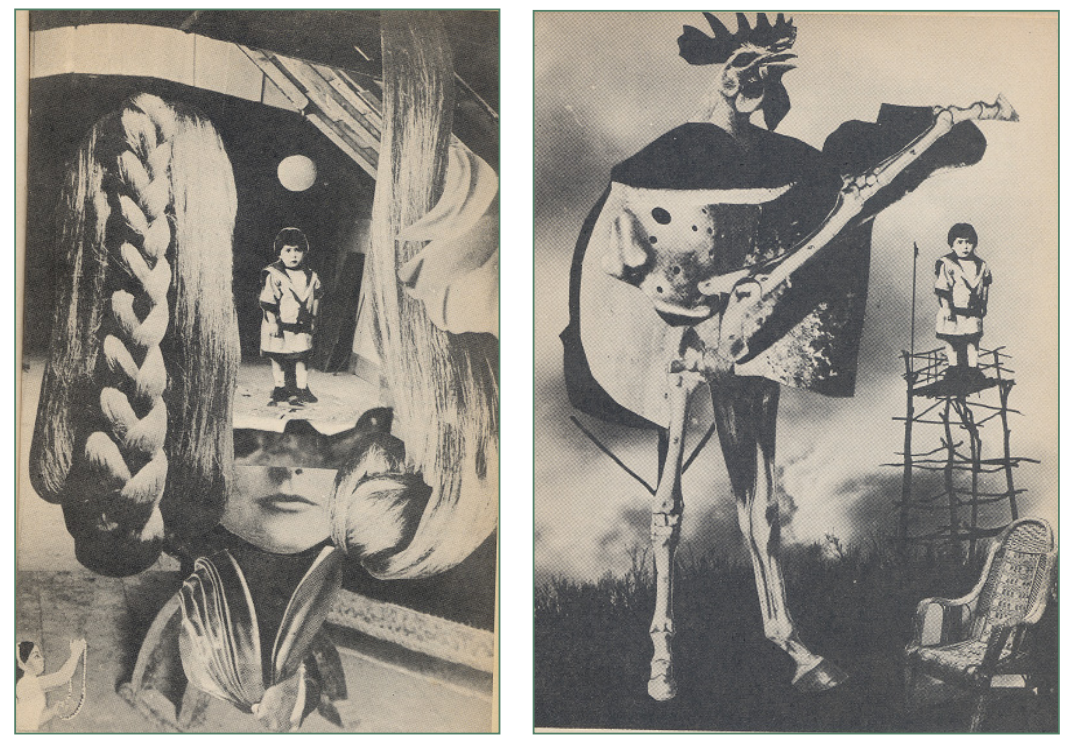

Enrique Molina: collages para La oscuridad es otro sol

La decisión de que sea una niña la que mantenga el hilo narrativo es acertadísima, por la diferente visión que otorga esa capacidad de la infancia para interpretar el mundo más allá de lo racional que ve un adulto. Dicha elección no obedece, como se ha dicho, al simple planteamiento de evocar el pasado desde la infancia, sino al hecho de poder acercarse e interpretar la realidad a través de los ojos no contaminados de un niño. La lectura de estos relatos nos transporta a esos momentos alucinados de la infancia en que se da otra dimensión a todo lo que sucede y nos rodea, y cuya validez en ese momento tiene mayor fuerza que la «real». De ahí que los actos y juegos de Lía sean, más que tales, ritos, y que se entregue a ellos «como a una ceremonia» (Loubet, 1996: 78), de forma que «lo más cotidiano, lo más conocido, empezando por el propio cuerpo y por la propia casa, se muestran bajo una faz insólita, perturbadora, inquietante, sorprendente» (Lojo, 2010: 360). Este conjunto de cuentos debe leerse pues como una «simbólica de la infancia», como «lugar poético» desde el que Orozco «funda su estilo existencial de habitar poéticamente el mundo», en una tensión a la vez angustiosa y dionisíaca entre la «mera realidad» y la «otra realidad» (Etcheverry, 2010: 399). En palabras de Jorgelina Loubet: 
Toda infancia es una fe en la existencia del mundo. Olga Orozco estaba señalada para el rescate de ese tumulto y esa fe. Su universo poético es mágico, tal como es mágico el universo para el niño, que no se vale de las categorías del entendimiento. [...] es onírico, tal como aparece el universo al niño que borronea las fronteras entre realidad y fantasía, esa realidad de la imaginación. [...] es apasionado como lo es el movimiento con que el niño se apodera del mundo; y es, por fin, empecinadamente indagador, como es empecinado el ¿por qué? cuando se instala en el labio infantil, reiterativo hasta espantar al adulto. (2010: 347-348)

La memoria, elemento constitutivo de La oscuridad es otro sol, no es privativa de la prosa, sino que ocupa un lugar de privilegio en el universo literario de la poeta. Como analiza Gustavo Zonana, la «evocación» por parte de la autora es «convocación»; es, en el sentido platónico, una anamnesis a través de la cual reconocer y unir las reminiscencias de aquellas imágenes originarias del yo que hacen unidad, que pertenecen a una dimensión trascendente (2002: 328-329). Junto a lo platónico, la simbología bíblica, la mitología griega, el tarot y Dante, Zonana descubre igualmente en estos relatos la huella de Marcel Proust; el recuerdo surge «de las profundidades del yo, desde un magma de olvido, conducido o provocado por los sentidos menos agudos, como el oído, el olfato, el gusto o el tacto, que compensan la falta de agudeza con la durabilidad de las sensaciones que provocan» (Zonana, 2002: 329).

Es esencial, por lo tanto, reiterar que no debemos tomar estos relatos como una simple remembranza nostálgica; son un instrumento de lucha, un golpear contra las puerta cerradas, giros en la rueda de un tiempo sin tiempos, reunión de todas sus identidades, del yo con el otro y de ello con el todo. Orozco - dice María Rosa Lojo- «excava en los depósitos antiguos de la imagen, en el ancho asombro de la infancia, en sus cuentos y los mitos que los subyacen, para encontrar, en esas 'canteras de resurrección', un nuevo modelo de la realidad, tramado en el bastidor de los grandes símbolos universales» (Lojo, 2010: 353).

Aunque Olga Orozco prefiere considerar este libro como una serie de relatos en vez de como una novela, lo cierto es que el hilo narrativo, los personajes, el tiempo y el espacio hacen que podamos concebirla como tal igualmente. Y, sumando a esa lectura, aproximarnos a ella también desde la lírica, pues esta -pese a la explícita diferencia y concepción que les otorgó la auto- 
ra- es innegable en múltiples pasajes del libro. Es esta la opinión de Cristina Piña, por considerar su naturaleza «más lírica que narrativa» (1984: 13); y la de Dujovne, que señala que Orozco narra en él desde la poesía y que el acercamiento a esta obra ha de hacerse a través de ella (1978: 2). Asimismo y por otro lado, el hecho de que el hilo narrativo lo mantenga una niña confiere al libro una singularidad respecto a los poemarios que no estriba solamente en la suplantación del verso por la prosa. «Hay épocas -observa Rebok- en que el tejido del texto de la vida está muy enmarañado y entonces conviene recurrir a un pre-texto para encontrar la trama verdadera, oculta en algún sub-o entre-texto. Los relatos de infancia son tan sólo o nada menos que ese pre-texto mediador, pero a precio de un 'vértigo hacia adentro'» (2010: 382).

\section{De la oscuridad al jardín}

En el inicio del primer cuento, encontramos ya la materia -y lo inmaterialbásica del libro, así como del resto de su obra: tiempo y espacio múltiples e indefinidos, un yo circular en ellos y una visión desde dentro, desde el revés del universo, de las cosas y de uno mismo. Un intento de trascender de todas las maneras posibles el espacio, el tiempo y el yo concretos, limitados, opacos, con todos los recuerdos a su alcance, incluidos aquellos inaprensibles que debe forzar a través de lo extrasensorial:

Había una vez una casa (no) Había en un tiempo una casa (no) Había en varios tiempos varias casas que eran una sola casa. ¿Era realmente una casa o era un espacio fraguado por los tres tiempos, de modo que cada uno era la consecuencia y el motivo del otro? Sí, como en los caleidoscopios o como en un yo circular a manera de cuarto de vestir, donde la que va a ser con máscara de anciana se probara la máscara de la que fue con máscara de niña, y viceversa y sucesivamente. La máscara de la que es, también, y que solo se ve desde adentro, desde el revés de todas las máscaras confundidas en una, hasta que se devore eso que habitualmente llamamos rostro y se pueda ver quién es quien lo devora, y entonces supongo que comprobaré lo que sospecho: que no se es uno sino todos. (5)

Ese «Había una vez» del título de este primer relato y de su inicio nos da pues las claves de interpretación. Olga Orozco vuelve a la casa de su infancia, la memoria la hace nacer de nuevo, nacer hacia adentro. Llega a una casa 
que la espera, una casa de la memoria cuya «verja se abre hacia su interior que desde ahora será afuera», y donde están todos, la abuela, el abuelo, papá y mamá, la tía Adelaida, sus hermanas, etc., que «son figuras que velan». Intuye que nacimiento y muerte son una misma cosa, que ella también es los otros, que además, «sin duda son otros tantos yo»; que su caída «es la caída de todos la caída de Dios en cada uno que no puede juzgarlo porque es el mismo Dios en tránsito hasta rehacer el cielo por encima de la disconformidad de su primera perfección». Y su destino le advierte que se verá arrojada «cada mañana a la misma condena de abrir inevitablemente cuando llaman aun cuando sienta que no hay nadie», y que ahora y en el porvenir será una «niñita encapuchada de azul [que] se ha quedado a solas con el azoramiento y el temor bajo las copos de nieve» (5-13). Finalmente, ese «había un vez» propio del inicio de los «cuentos de hadas», nos sitúa de inmediato en el entorno mágico de los mitos, dando al lector el mensaje de la posición desde la que debe abordar su lectura.

Todo comienza pues con un nacimiento, que es en realidad un regreso; no sale a un lugar, entra en él; proviene no sabe de dónde para arrojarse «de cara al vacío contra los cristales de la oscuridad». Lo que encuentra al nacer es un gran muro que la mira «con mirada ciega» mientras, en el fondo, queda el jardín (6); ese jardín simbólico del que ha sido arrojada y cuya intuición le hará proseguir en su empeño de traspasar esa puerta que se cerró. Formalmente, para representar ese momento, Orozco utiliza, tras los primeros párrafos, uno de más de seis páginas sin puntuación ni pausas que es un fluir en un deslizamiento paralelo al que a Lía le está sucediendo en el momento del parto: nacimiento y muerte; llegada y regreso. Y, finalmente, el relato cierra así: "Giro como la tierra adentro de ese pozo. Algo me aspira. Subo. Mamá, papá, yo: eclipse sobre la esperanza de una raza» (13). Esa luz-oscuridad a la que sale, y esa oscuridad-sol que deja atrás son las que entretejen la realidad simbólica de Lía, que se mezcla sin solución de continuidad con la voz adulta. En uno de los últimos cuentos concluye:

La niña y la anciana están ahora en mí [...]. Intento mirar con sus ojos esta puerta para detenerla, para que se corra hacia delante o hacia atrás [...]. Y de pronto no hay puerta, ni infancia, ni vejez. Estamos dentro de la escena. Una unidad de tiempo, de lugar y de acción ha convocado aquí los siglos, las distancias y los actos (165). 
Solo se intuye el instante, después cada una de las dos vuelve a su lado sin que sea posible traspasar la línea que las separa. Pero, aunque no lo consigue, la muerte, personaje que encarna con un vestido «lila grisáceo que precede a la desaparición» se instala definitivamente en uno de los rincones de su cuarto, y su presencia es a la vez amenaza y esperanza. La muerte, tan presente en su poesía y en este libro, aparece ya en el segundo relato, « $Y$ todavía la rueda», justo tras el nacimiento, cerrando un círculo gnosticista, panteísta y mistérico que la ayudará a comprender. Se enfrenta a ella a muy temprana edad, cuando se lleva a su hermano Alejandro. Su familia la aleja por unos días de la casa familiar, pero su inevitabilidad la alcanza, y siente como «si el viento hubiera pasado por mi casa cerrando de golpe una puerta que encontraremos cerrada para siempre al regresar» (16-17). Es un paralelismo con el nacimiento, ya que se nos cierra una puerta infranqueable, y se nos veda igualmente el conocimiento. En el relato, su abuelo la trae, a caballo, de regreso a casa desde Telén a Toay, en una marcha «irrevocable», como si fueran «adentro de una rueda», pero la oscuridad y una gran tormenta de lluvia y truenos los sorprende. El camino se desdibuja y se mezclan y anticipan otros momentos de su vida con ese que la está llevando al encuentro con la muerte. Siente que algo se está tejiendo detrás de sí,

como si ese atrás fuera la noche entera que se se está enredando para envolvernos. La siento trabajar, muy cerca, agazapada entre los matorrales agitados [...] la siento preparar sus materiales [...] tender a los costados las apretadas telas con que habrá de ceñirnos. (19)

Entonces siente miedo, un gran vértigo hacia abajo y hacia adentro, «como una piedra fría por la boca del estómago, quién sabe hasta qué profundidad», y se aferra a las crines del caballo en una lucha por asirse «desde afuera». Se pregunta, en medio de la «rueda de la náusea»: «¿Por qué me están volviendo del revés? ¿Y hasta cuándo?» (19-20). La tormenta se agita, y entonces,

Algo se acerca. Algo viene rodando por el camino sin ninguna rueda. Entre dos parpadeos del relámpago distingo una nebulosa. Es un inmenso organismo parduzco y espinoso, hecho de atmósfera y de agresividad. [...] pertenece al mundo de la repetición insondable, que crece por fuera.

[...] ¿Quién sabe desde qué distancia ordena que este emisario de la fatalidad emita una prolongación desde lo informe [...]. Y bien, que llegue, 
que nos invada, que nos convierta en otra adherencia idéntica al resto de su erizada nada. Caballo, anciano y niña seguiremos con las agujas del reloj hasta la absurda consumación del absurdo universo. Pero no; pasa rozándonos y sigue. Y seguirá creciendo en su aridez, agregando a su mole gigantesca otras moles idénticas, desenraizadas y sin un destino final. [...]

-Era un cardo ruso -dice sencillamente el abuelo Damián4. (22)

Pasan también junto al muro del cementerio. Los muros, las paredes, que se repiten en toda su obra, tienen el simbolismo de la infranqueabilidad entre el lado terrenal y el de lo absoluto: «acabo de ver, estampadas en brumas por la mirada de la lluvia, las cúpulas con cruces absortas que se asoman desde lo alto del muro y encima del portal el ángel irremediable que nos llama» (25). Cuando al fin llegan a la casa, y su abuelo la deposita en el suelo, se siente «algo sin principio ni fin, sin manos y sin pies [...] desplazada todavía por el empuje de la rueda que ahora gira desparejada en el vacío del corazón» (28). Así pues, desde el título, hasta el final del relato, que se cierra con la sentencia directa "Y todavía», se elimina toda linealidad del tiempo, todo principio y fin. Un todavía que engarza, igualmente a modo de círculo narrativo, con el penúltimo relato, «Unas tijeras para unir». En él, la muerte es la de su madre -que lo está hace ya veinte años-, a quien le pide -al igual que en el poema «Si me puedes mirar» de Los juegos peligrosos- que le permita abrir esa puerta que las separa y hace imposible el paso entre ambos lados. Porque es la única manera de conjurar el sentimiento de orfandad que se experimenta en este lugar al que somos expulsados al nacer. A través de la muerte roza la puerta de lo sagrado, del tiempo y el espacio que habitan los muertos, y se deleita en el hilo del miedo y del vértigo, de lo que atisba pero no conoce.

Miedo y vértigo que experimenta de nuevo en el relato «Misión cumplida». Lía, junto a sus amigos y sus hermanas, han creado una organización de espías. En una de las «misiones» que llevan a cabo, el grupo se divide para salir a «observar», y reunirse después para contar cada cuál algo «extraordinario» que haya visto. Entonces la muerte la golpea de nuevo, pues se encuentra, oculto en medio de un campo de girasoles, un cuerpo tendido bocabajo con un

4 El cardo ruso, llamado también en Argentina cardo del diablo, es una planta espinosa como de un metro de alto, cuyas ramas se curvan hacia adentro dándole el aspecto de un gran globo. Cuando la planta llega a la madurez se desprende del suelo. Ruedan entonces con el viento y van aumentando su tamaño a medida que se trasladan, al ir adhiriéndosele lo que encuentra a su paso. Son comunes en la Pampa. 


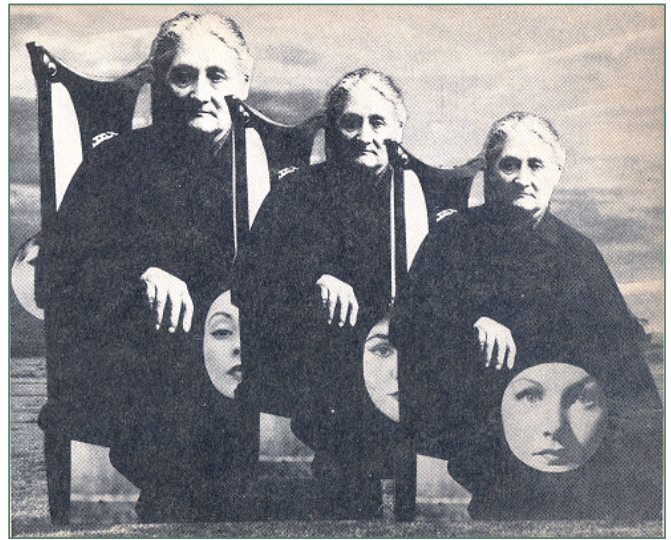

Enrique Molina: collage para La oscuridad es otro sol

charco de sangre bajo su cabeza. Su respuesta es la huida y el silencio, no contar nada, porque de alguna forma se siente ligada al muerto, con su imagen petrificada amarrada a ella. En este caso se trata de una muerte asociada al crimen, que vuelve a estar presente en otro relato, «¿Por qué están tan rojas las begonias?», donde exploran una casa en la que el dueño había matado a toda su familia: madre, esposa e hijos.

Así pues, como estamos viendo, la indagación del tiempo y de la muerte es sin duda uno de los motivos vertebradores de La oscuridad es otro sol y de toda su obra, en un intento de quemar todas las edades, de barajarlas para poder abolir los límites que se nos imponen desde el nacimiento. En el poema «Variaciones sobre el tiempo», de Mutaciones de la realidad (1979), se encara con él $\mathrm{y}$, tras reconocer sus victorias, le dice:

Tampoco te concedí una tregua.

Violé tus estatutos.

Forcé tus cerraduras y subí a los graneros que denominan porvenir.

Hice una sola hoguera con todas tus edades.

Te volví del revés igual que a un maleficio que se quiebra,

o mezclé tus recintos como en un anagrama cuyas letras truecan el orden

y cambian el sentido.

Te condensé hasta el punto de una burbuja inmóvil, opaca, prisionera en mis vidriosos cielos.

Estiré tu piel seca en leguas de memoria,

hasta que la horadaron poco a poco los pálidos agujeros del olvido.

Algún golpe de dados te hizo vacilar sobre el vacío inmenso entre dos

horas. (2000:156)

Volviendo a «Y todavía la rueda», podemos constatar fácilmente cómo ese retorno a casa se muestra al modo de un viaje iniciático, marcado por numerosos símbolos reconocibles: la rueda, que no sólo es la del des- 
tino, sino también la que permite volver atrás; la tormenta, a modo de un naufragio o diluvio bíblico, desdibuja los contornos espacio-temporales abriéndose en una nueva dimensión; el precipicio con su miedo y su atracción a la vez por lo desconocido; el río de aguas agitadas y peligrosas que es necesario atravesar; la noche que lo envuelve todo... y, al final -«al final de todo desfallecimiento, de toda tenacidad»-, la casa (23). Sin embargo, y en ello estriba la singularidad de la autora, no le será dado al cerrar el periplo, el premio o la certeza que se le concede al héroe, sino solo, y de nuevo, la capacidad de interrogar, la incertidumbre sobre las puertas o los abismos que unen la vida y la muerte. Orozco, según sus propias declaraciones, ha buscado expresamente el tono mitológico, marcando a los personajes con el destino fijo, ejemplar e inalterable de los héroes, para convertirlos en «mitos actuales», en mitos «modernos» (cit. en Legaz, 1993: 377). Porque el mito -dice Legaz- «intenta devolver al hombre su perdida unidad, reinstalándolo en su dimensión ontológica total» (1993: 376); esa es la búsqueda principal de Orozco en toda su obra, y su permanente necesidad de conocer.

Muestra de igual forma similitudes con el relato de viaje, porque «lo que importa no es tanto el punto de llegada, ni la trama de las acciones del viajero, sino aquello que se ve y se vive e medida que se avanza», en este caso realizado, además, por «una niña cuya alma es muy vieja, porque llega desde el fondo del tiempo, desde existencias que resurgen a veces mediante los juegos audaces de una memoria transpersonal» (Lojo, 2010: 272-273).

Este enfoque épico es ampliable a toda su obra -prosa y verso-, como demuestra María Rosa Lojo, para quien «la poesía de Orozco converge, en sus estratos profundos, con lo ancestral de la memoria humana», entroncado con «los grandes símbolos universales». Su poesía es -afirma- «una épica del tránsito de la humanidad por el 'reino de este mundo', buscando sobre sus huellas los atisbos del otro». Igualmente descubre Lojo una particular originalidad en la obra de Orozco respecto a otros buscadores de lo absoluto, por su relación con lo feérico, con el cuento de hadas, así como por el hecho de que en este caso la aventura heroica sea femenina (Lojo, 2010). Tanto ella como los personajes que ejercen un papel relevante en la exploración metafísica hacia lo desconocido son femeninos: la abuela está asociada 


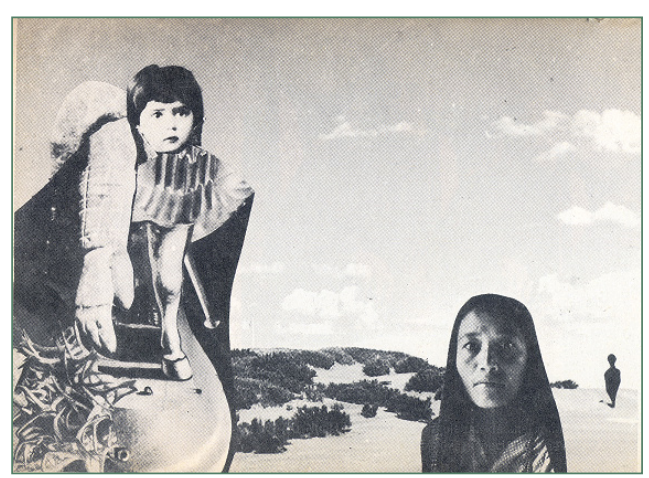

Enrique Molina: collage para La oscuridad es otro sol a lo mágico, es una «hechicera blanca»; la madre es invocada para que le tienda un puente entre los tiempos; la Lora y la Reina Genoveva se asoman a la locura; la curandera María Encarnación; la bruja Teo; sus hermanas, etc.; e incluso la casa, que tiene una enorme importancia (Lojo, 2010: 371-374). Los personajes masculinos tienen otro tipo de protagonismo y no en este sentido.

Otro de los relatos especialmente reveladores es «DTG 4». El título es la sigla de la citada organización de espías formada por el grupo de amigos para el juego. En él, cada cual debe llevar a cabo un ritual de iniciación. Uno de los chicos, para «exhibir de manera irrefutable su condición de jefe», roba el florero de opalina celeste que lucía en el nicho de don Nino Calcavecchia, y el resto igualmente lleva a cabo iniciaciones que acrediten su «coraje masculino». En cambio, las pruebas a las se someten ellas son hacia el interior. Así, Ruth debe identificar a los demás por las manos, tocándolas con los ojos cerrados; Laura debe adivinar quién y qué hace cada cual mientras permanece encerrada dentro de un armario; y Lía debe permanecer inmóvil encerrada en una bolsa hasta que vengan a por ella. Allí espera y espera y, en la soledad y la oscuridad, alejada de todo lo sensorial, es donde su percepción se agudiza más allá de los sentidos. Porque «la oscuridad tiene ojos también, ojos que podrían ser una salida» (57). Son dos formas de enfrentarse al mundo, dos formas de aprehenderlo. En un inquietante pasaje que rememora el poema «Lamento de Jonás», de Museo salvaje, relata el descubrimiento de sus percepciones: siente ser un oscuro organismo dentro de otro que «solamente late y anonada y filtra en sus vísceras innominadas toda la fe, toda la esperanza y todas las razones», hasta lograr un vacío donde el tiempo está suspendido, y a la vez la existencia. No puede salir, porque para ello tendría que hacerlo también de su organismo, en el que se siente «incrustada», como si la bolsa en que está metida estuviera cosida «con puntadas que no tienen revés» (57-58). Y empieza a caer, a caer hacia adentro de sí misma, 
totalmente desposeída de toda realidad, de toda cohesión: un puñado de partículas llevadas por el azar hacia una fatalidad jamás prevista, en la que sólo perdura un sabor de vísceras que devoran el hartazgo de sí mismas, la repugnancia de su sobrevivencia insípida o de su presencia demasiado viva todavía en esta nada. (58)

Se percibe entonces como solo «una adherencia de esta nada». La caída sigue largamente, pero al final se vislumbra «un jardín» y se aferra a esa imagen preguntándose si será aquello lo que estaba esperando. La imagen del jardín, igualmente, es clave en la poética de Orozco. Recordemos que en su nacimiento, mientras se sentía caer, dijo: «En el fondo hay un jardín» (6). También ahora, encerrada en la bolsa, tras experimentar esa desconexión de toda referencia exterior y percibir que solo es «un resto de memoria insistente y sin sentido», vuelve a repetirse: «'En el fondo hay un jardín. En el fondo hay un jardín. En el fondo hay un jardín'. ¿Será esto lo que vine a explorar?» (58). Concuerdo con Jacobo Sefamí en que el episodio de este relato es fundamental para comprender la poesía de Orozco (1993, 140-141).

Igualmente preeminente es la presencia de una serie de personajes extravagantes, tocados de una u otra forma por la locura y el infortunio: La Lora, que vive en una cueva con su hijo en medio de un campo de girasoles, viste de pordiosera y con un gran sombrero amarillo, como si fuera uno de ellos. Su marido hirió a su propio hermano al descubrir que ambos eran amantes. Ambos huyeron y ella quedó embarazada, sola y trastornada, y enmaraña entonces su propia historia con la de los relatos bíblicos de Caín y Abel, y con la concepción de la Virgen María; Nanni es un tenor fracasado que se siente desdoblado en dos, él y su impostor; la Reina Genoveva es una mujer que había sido abandonada con su hijita pequeña, que murió pronto; se asimila en los relatos a una muñeca metida en una caja llena de bolas de alcanfor, y es también una muerta en vida enterrada en la nieve. Se asocia en ocasiones a la maldad. Estos personajes son protagonistas en varios relatos: «iDespertad y cantad, moradores del polvo! », «Nanni suele volar», "Comida para pájaros» $\mathrm{o}$ «Bazar de luces rotas». Lía-Olga intuía que a través de ellos podría encontrar respuestas que eran especialmente idóneas para acercarse a ese abismo entre mundos en el que transitaban: «Me daba cuenta de algún modo secreto y remoto -confirma Orozco- que era gente que había traspasado una frontera y que, entonces, tenían un conocimiento misterioso que yo no tenía 
y del que me podían dar algún atisbo si yo sabía descubrirlo» (cit. en Torres de Peralta, 1987: 45). Son «heraldos de lo imprevisible e insólito, de ese otro mundo agazapado en este» (Rebok, 2010: 386). Para Lojo, estos seres reinterpretan sus lastimosas vidas «en una dimensión estética (Nanni), maravillosa (la reina Genoveva) o sobrenatural/sagrada (la Lora), que vuelve a darles el sentido que perdieron» (2010: 367). Ella también sabe acercarse a la locura, a esa «zona verde cruel fermentada por presencias insólitas, por objetos malvados y reflejos equívocos, que aparecen y desaparecen, como las alimañas, a través de las puertas entreabiertas o entre las colgaduras» («Bazar de luces rotas», 149), siente que esa «zona verde» la invade, pero le da la vuelta preguntándose: «¿No está más bien en la región donde comienza lo sagrado?» (153).

El amor, otro de los temas abordados, se muestra igualmente despojado de los límites espaciotemporales, es un amor circular, parte del resto de los amores de su vida. Así, el rostro de Miguel, su primer amor, pese a ser singular y describirlo con detalle, es la «conjunción de otros rostros que llegarían después», sus rasgos se dispersaron y fue encontrándolos y amándolos en otros rostros y otros tiempos («¿Por qué están tan rojas las begonias?»: 104-105).

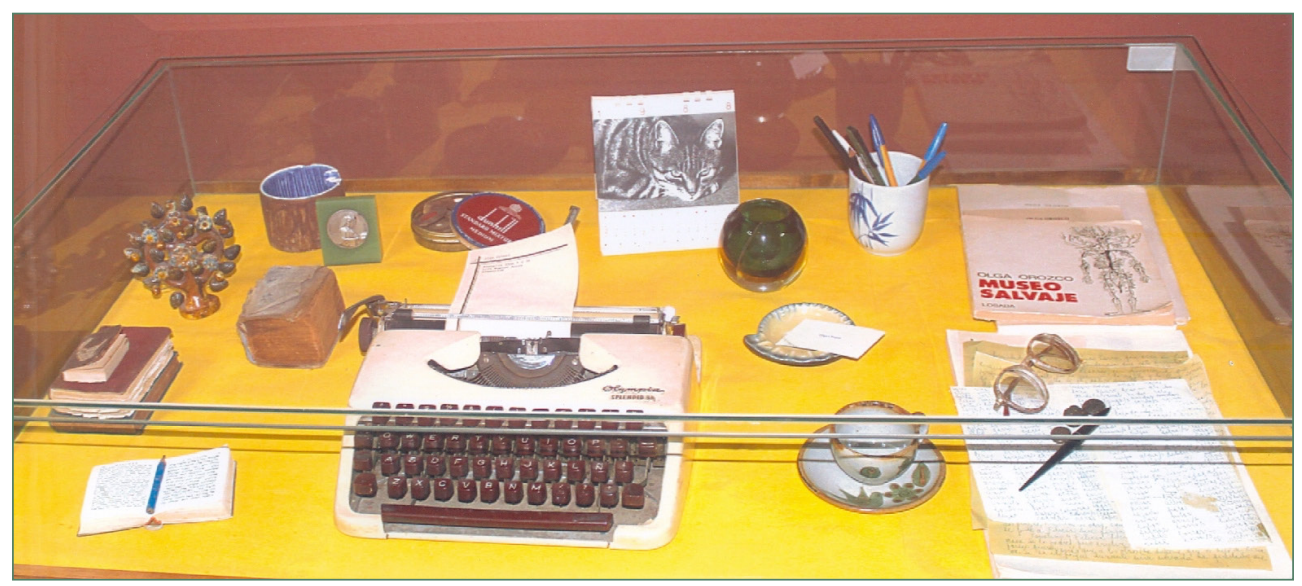

Objetos personales de la autora. Casa Museo de Olga Orozco en Toay

Y unido al amor el recelo de perderlo, el miedo a la herida y, sobre todo, a la soledad, pues ni siquiera el amor será capaz de vencerla. Es el amor el que pone fin a la infancia, en correspondencia con el momento en que se 
marchan de la casa. Es otro abandono, como el experimentado al nacer en el primer cuento. Pero el dolor es noble, según proponía Nietzsche, y además es fecundante, por eso en la poética orozquiana, la búsqueda y la gestación de su obra no es posible sin este componente básico (Etcheverry, 2010). Y por ello, aquella pequeña piedra que Miguel le entregara en ese momento, como compromiso de reencuentro, acompañó siempre el acto escritural de la poeta durante toda su vida.

Igualmente tienen cabida en los relatos el resto de los mitemas propios de la poética de Orozco: la asimilación del yo al tú y al todos nosotros; la multiplicidad, en fusión con todos y con todo hasta la confusión entre los límites de lo propio y lo ajeno; y con ello la idea de Dios que, en una concepción panteísta, es también el Hombre, un hombre que ha perdido en su vida terrenal la plenitud, y por eso es asimismo la imperfección, una imperfección que alcanza igualmente a Dios. Orozco indaga el misterio de lo sagrado en orden inverso: más que «urdir una prueba de la existencia de Dios», «reclama una prueba de su propia existencia» (Rebok, 2020: 391), y vuelca en el texto las certidumbres conseguidas tras su doloroso y arriesgado viaje al subconsciente y las necesarias interrogantes que las acompañan:

Sí, ¿para qué nos creó? ¿Y por qué nos creó así? Justamente, nos creó para visualizar en imágenes su disconformidad, para perfeccionarse. Y se repartió de tal modo entre nosotros que tal vez ya no esté en ninguna parte, fuera de nosotros; tal vez vuelva a ser él, feliz, cuando cada uno seamos lo que él quería para su unidad. Tal vez consumamos, viéndola, la parte de mal que lo aquejaba. Tal vez pueda volver entonces a recuperar su unidad, mejorada. Ignoro para qué (170).

Y en todo ello, está asimismo presente el tema de la caída originaria, y el dolor que produce esa separación que no podrá aliviarse hasta después de la muerte, «momento en que, según en gnosticismo, el alma que logre redimirse se unirá a su doble del cielo, y, a través de él, a Dios» (Piña, 1984: 18). Su esperanza está puesta, por lo tanto, en la unidad que aquí se le niega, pero que encontrará al retornar al lugar de donde fue expulsada. Una unidad que, repito, incluye a todo y todos: «no soy todo; soy con todo. [...] Cada uno es los otros, y mi nombre y el tuyo son sólo una impostura» (153). En «Y después ya no estaban», la imagen que utiliza del espejismo del agua en la arena es significativa; donde ahora hay arena, en un tiempo estuvo el mar: «A 
veces, cuando vamos en la volanta por el camino, se ve el agua que se aleja, y no llegamos nunca adonde está. Es como un juego que no es alegre ese del agua muerta convertida en fantasma» (67).

Y dedica el último de los relatos, «Juegos a cara o cruz» a describir algunos de esos juegos arriesgados y «peligrosos « de su anterior poemario: primero juega a «la invisible», para lo cual, con un concentrado esfuerzo de voluntad, deja que la atraviese el aire libremente haciendo «de esa vibrante transparencia un depósito central», que «la impelía en todas las direcciones hacia fuera, hasta traspasar la piel», mientras extraía las formas que albergaba su cuerpo a medida que lograba la transparencia (171).

El segundo, «para ser otra», consiste en repetir el propio nombre hasta hacer «trizas el yo»; asomarse después, a la luz de una vela, a un espejo, y adentrarse en ese yo que no es ella. Van surgiendo entonces las otras que son ella y que también aparecen en su poesía: Matrika Doléesa, reina salvaje en la que está «la tensión del salto que la arrancaría a la danza ritual y luego al sacrificio»; Griska Soledama, triste huérfana «para todas las pruebas de desplazamiento en la intemperie»; Darmantara Sarolam, «que une todos los nombres, todos los hilos del destino desde un carruaje cuyas ruedas son dos soles» (174); nombres mágicos, inquietantes, oscuros. Y precisamente lo que Gabriela Rebok considera la clave interpretativa del libro, lo que convierte la oscuridad en «otro sol», reside precisamente en las categorías kierkegaardianas de la «repetición» y en el recurso a la «máscara lingüística», al pseudónimo, pues en ellas encuentra la posibilidad de reinstaurar el «aliento de los orígenes» (2010: 379).

El espejo aparece también en el temeroso recorrido que hacen cuando incursionan en la casa del asesino múltiple en «¿Por qué están tan rojas las begonias?». Se topa con un espejo polvoriento y blanquecino, y la imagen reflejada en él la sorprende y estremece: « $i Y$ si no fuera yo»-se pregunta- « $\mathrm{O}$ si estuviera allí y no aquí?» (103). Y de igual forma es un espejo el que trunca su amor y le devuelve dolor. Ella había depositado con amoroso cuidado un beso en el lugar donde se había reflejado la cara de Miguel junto a la suya, pero un poco más tarde es el espejo también quien le ofrece la imagen de Miguel junto a su amiga Ruth en otra de las habitaciones.

En un tercer juego, «las antípodas», lleva al límite el desdoblamiento y dualismo entre el «yo» y el «otro». Tiene la certeza de que su antípoda la sos- 
tiene, y ella a él, de forma que, «cuando él se desplaza, me desplazo; cuando me arrojo al mar, se arroja o cae al mar; cuando viajamos, viajamos en direcciones contrarias para permanecer en la misma referencia» (176). La manera de encuentro, la solución para poder reunirse, es doble: por un lado, «conseguir un ángulo de $180^{\circ}$ que empezara a cerrarse, irrevocablemente»; pero por otro, y es el que prefiere, «excavar hasta encontrarnos en esa masa ígnea, en esa pepita de fuego que está sepultada en el interior del globo, y arder, arder en un fuego mutuo hasta consumirnos en la misma llama» (177). Es una manera de volver a la materia primigenia, al magma previo a la formación de su propio planeta. Los tres juegos consisten en, de una u otra forma, hacerse desaparecer, y es con ellos con los que significativamente cierra el libro. Se anula, pero para encontrarse.

En definitiva, Olga Orozco mantiene y desarrolla en La oscuridad es otro sol las mismas inquietudes y motivaciones de su obra poética. Se trata de violentar las fronteras del tiempo y del espacio en las dos direcciones: hacia abajo, a través del ocultismo, la magia, el tarot, los sueños, los juegos peligrosos; y hacia arriba, a través del gnosticismo, el misticismo y la espiritualidad. El acto creador se convierte así en «exploración de todos los sentidos de lo desconocido a través del desarreglo de los sentidos», en «ordenamiento de fuerzas misteriosas sometidas a la razón», en «correlaciones íntimas entre el lenguaje y el universo» (Orozco 1985, 10). Y no se trata de fáciles recursos retóricos sino del eje central de su poesía, el que vertebra toda su estructura metafórica. Serían deseables en este sentido nuevos acercamientos a esta obra focalizados en el análisis de sus rasgos estilísticos -tan ricos-, del uso de las imágenes y del lenguaje metafórico, tan peculiares como inquietantes.

\section{Referencias bibliográficas}

CARrión, Ana Gabriela, «La oscuridad es otro sol: mito y rito en los relatos de infancia de Olga Orozco», trabajo final de licenciatura, Córdoba (Argentina), julio de 2013. Consulta 25-10-2020, <https://rdu.unc.edu.ar/bitstream/handle/11086/2745/La\%20oscuridad \%20es\%20otro\%20sol\%20 tfl\%20(1).pdf?sequence=1\&isAllowed $=y>$

ETCHEVERrY, Luis María (2010), «Olga Orozco y la prosa, un deslumbre demorado. Una simbólica de la infancia y la máscara», en Inmaculada Lergo 
Martín (ed.), Olga Orozco. Territorios de fuego para una poética, Sevilla, Secretariado de Publicaciones de la Universidad de Sevilla, 397-416.

Dujovne Ortiz, Alicia (1978), «Los ritos de la vida y de la poesía en la obra de Olga Orozco» (entrevista), en La Opinión Cultural, Buenos Aires, 22 de enero, 1-3.

Legaz, María Elena (1993), «El mito en los relatos de infancia de Olga Orozco», en Actas del VII Congreso Nacional de Literatura Argentina Tucumán, 18 al 20 de agosto de 1993, Tucumán, Universidad Nacional de Tucumán-Facultad de Filosofía y Letras, 376-385.

LERGo MARTín, Inmaculada (2010): «Decir lo indecible. Olga Orozco o la revelación a través de la palabra», en Inmaculada Lergo Martín, Olga Orozco. Territorios de fuego para una poética, Sevilla Secretariado de Publicaciones de la Universidad de Sevilla, 23-106.

Loubet, Jorgelina (2010): «Relectura de La oscuridad es otro sol, de Olga Orozco», en Inmaculada Lergo Martín, Olga Orozco. Territorios de fuego para una poética, Sevilla. Secretariado de Publicaciones de la Universidad de Sevilla, 347-351.

Lojo, María Luisa (2010), «Olga Orozco: Épica y Poética en un largo cuento de hadas», en Inmaculada Lergo Martín, Olga Orozco. Territorios de fuego para una poética, Sevilla, Secretariado de Publicaciones de la Universidad de Sevilla, 353-375.

Orozco, Olga (1985), páginas introductorias a Antología poética, Madrid, Cultura hispánica-Instituto de Cooperación Iberoamericana.

- (1991), La oscuridad es otro sol, Valencia, Pre-Textos [Primera edición, Buenos Aires, Losada, 1967].

- (2000), Obra poética (edición de Manuel Ruano), Caracas, Ayacucho.

PIÑA, Cristina (1984), «Estudio preliminar» a Olga Orozco, Páginas de Olga Orozco seleccionadas por la autora, Celtia, Buenos Aires, 13-54.

Reвок, María Gabriela (2010), «La repetición o el umbral de la creatividad. Un conjuro de la experiencia trágica», en Inmaculada Lergo Martín, Olga 
Orozco. Territorios de fuego para una poética, Sevilla, Secretariado de Publicaciones de la Universidad de Sevilla, 377-395.

Requeni, Antonio (ed.) (1997), Olga Orozco/Gloria Alcorta, Travesías. Conversaciones coordinadas por Antonio Requeni, Buenos Aires, Sudamericana.

Ruano, Manuel (2000), «Constantes míticas, esotéricas y surreales en la poesía de Olga Orozco", en Olga Orozco, Obra poética (edición de Manuel Ruano), Caracas, Ayacucho.

Sefamí, Jacobo (1993), «Olga Orozco: El revés del poema», en De la imaginación poética. Conversaciones con Gonzalo Rojas, Olga Orozco, Álvaro Mutis y José Kozer, Caracas, Monte Ávila, 1996, 93-149.

SAUTER, Silvia (2006), «Entrevistas a Olga Orozco», en Teoría y práctica del proceso creativo, Madrid-Frankfurt, Iberoamericana-Vervuert, 2006: 7-16. También en Perlego, consulta 22-10-20, <https://www.perlego.com/ book/1164288/teora-y-prctica-del-proceso-creativo-con-entrevistas-a-ernesto-sbato-ana-mara-fagundo-olga-orozco-mara-rosa-lojo-ral-zurita-y-jos-watanabe-pdf>

Torres de Peralta (1987), La poética de Olga Orozco. Desdoblamiento de Dios en máscara de todos, Madrid, Playor.

Zabaljáuregui, Horacio (1998), «Prólogo» a Olga Orozco, Relámpagos de lo invisible. Antología, Buenos Aires, Fondo de Cultura Económica. También en DocPlayer, consulta 22-10-20, <https:/ / docplayer.es/94705647-Relampagos-de-lo-invisible.html>

ZONANA, Víctor Gustavo (2002), «Imágenes de la memoria en la obra de Olga Orozco», Boletin de la Academia Argentina de Letras LXVII, 265-266 (2002): 325-345. También en Cervantes virtual, consulta 22-10-2020, <http:/ / www. cervantesvirtual.com/servlet/SirveObras/01479674511225028537857/ p0000018.htm\#I_76_> 